\title{
Echocardiographic parameters as predictors of survival in patients with chronic heart failure: the relevance of "classic" parameters in the modern era
}

\author{
Marijan Pašalić*, \\ Gloria Lekšić, \\ Jasmina Hranjec, \\ Boško Skorić, \\ - Jure Samardžić, \\ Jana Ljubas Maček, \\ Daniel Lovrić, \\ Hrvoje Jurin, \\ Olvo Planinc, \\ Dora Fabijanović, \\ Nina Jakuš, \\ Maja Čikeš, \\ Davor Miličić
}

University of Zagreb School of Medicine, University Hospital Centre Zagreb, Zagreb,

Croatia
KEYWORDS: heart failure, cardiomyopathy, echocardiography, mortality

CITATION: Cardiol Croat. 2017;12(9-10):359-360. I https://doi.org/10.15836/ccar2017.359

*ADDRESS FOR CORRESPONDENCE: Marijan Pašalić, Klinički bolnički centar Zagreb, Kišpatićeva 12, HR-10000 Zagreb, Croatia. / Phone: +385-1-2367-467 / E-mail: marijan.pasalic@yahoo.com

ORCID: Marijan Pašalić, http://orcid.org/0000-0002-3197-2190 • Gloria Lekšić, http://orcid.org/0000-0003-4649-7764 Jasmina Hranjec, http://orcid.org/0000-0001-8356-7376 • Boško Skorić, http://orcid.org/0000-0001-5979-2346 Jure Samardžić, http://orcid.org/0000-0002-9346-6402 • Jana Ljubas Maček, http://orcid.org/0000-0001-7171-2206 Daniel Lovrić, http://orcid.org/0000-0002-5052-6559 • Hrvoje Jurin, http://orcid.org/0000-0002-2599-553X Ivo Planinc, http://orcid.org/0000-0003-0561-6704 • Dora Fabijanović, https://orcid.org/0000-0003-2633-3439 Nina Jakuš, http://orcid.org/0000-0001-7304-1127 • Maja Čikeš, http://orcid.org/0000-0002-4772-5549 Davor Miličić, http://orcid.org/0000-0001-9101-1570

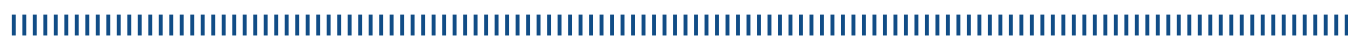

Introduction: Chronic heart failure (HF) has become one of the most prominent health issues of today and despite advances in treatment, HF mortality rates remain high. Echocardiography plays a crucial role in the diagnosis and management of HF patients. ${ }^{1}$ The aim of this study was to reevaluate the role of "classic" echocardiographic parameters in predicting the mortality of patients with HF across various cardiomyopathies.

Patients and Methods: We retrospectively analyzed data from 200 patients ( $71 \%$ male, $47.8 \pm 11.7 \mathrm{y}$ ) with mild to moderate chronic HF (NYHA II and IIIa) treated at our Department from December 2010 until December 2014. All patients underwent a standardized echocardiographic examination. Left ventricular systolic/diastolic (LVIDs, LVIDd) and left atrial (LA) dimensions were determined using M-mode analysis in the long-axis parasternal view. Left ventricular ejection fraction (LVEF) was calculated using both 2D measurements and Simpson Biplane method. Right ventricular function was evaluated using tricuspid annular plane systolic excursion (TAPSE). The last patient follow-up was performed via telephone interview, with a mean follow-up period of $44.9 \pm 16.5$ months. The primary outcome of the study was overall survival.

Results: Most of our patients presented with HF due to ischemic and dilated cardiomyopathy (26.5\% and 25\% respectively). Overall patient survival was 92.5\%. LVIDd, LVEF, LA and TAPSE differed significantly among the survival groups (Table 1). When comparing survival curves, LVEF lower than $35 \%$, LA smaller than $4.6 \mathrm{~cm}$ and TAPSE lower than $16 \mathrm{~mm}$ were all found to be predictive of adverse outcome (Figures 1, 2, and 3). Regression analysis revealed LVIDd and LA to be the best predictors of mortality in our patient population $(\operatorname{Exp}(B)=1.8, P=0.038$ and $\operatorname{Exp}(B)=2.0, P=0.037$ respectively).

\section{TABLE 1. Comparison of echocardiographic parameters according to survival groups.}

\begin{tabular}{lccc} 
ECHO parameter & $\begin{array}{c}\text { Patients without primary } \\
\text { outcome }\end{array}$ & $\begin{array}{c}\text { Patients with primary } \\
\text { outcome }\end{array}$ & P-value \\
\hline LVIDd $(\mathbf{c m})$ & $6.6 \pm 1.1$ & $7.3 \pm 0.6$ & $0.02 *^{*}$ \\
\hline LVIDs $(\mathbf{c m})$ & $5.5 \pm 1.6$ & $5.5 \pm 2.1$ & 0.514 \\
\hline LVEF (\%) & $32.3 \pm 14.8$ & $23.9 \pm 8.8$ & $0.033^{*}$ \\
\hline LA $(\mathbf{c m})$ & $4.6 \pm 1.0$ & $5.2 \pm 0.7$ & $0.032 *$ \\
\hline E/e' & $19.1 \pm 13.0$ & $16.0 \pm 5.8$ & 0.970 \\
\hline TAPSE $(\mathrm{mm})$ & $16.5 \pm 4.6$ & $12.8 \pm 2.9$ & $0.008 *$ \\
\hline
\end{tabular}

LVIDd = left ventricular internal diameter end-diastole, LVIDs = left ventricular internal diameter end-systole, LVEF = left ventricular ejection fraction, LA = left atrial diameter, EoEp = E over E prime, TAPSE = tricuspid annular plane systolic excursion.
RECEIVED:

September 24, 2017

ACCEPTED:

September 26, 2017

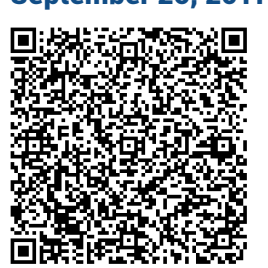

(1)




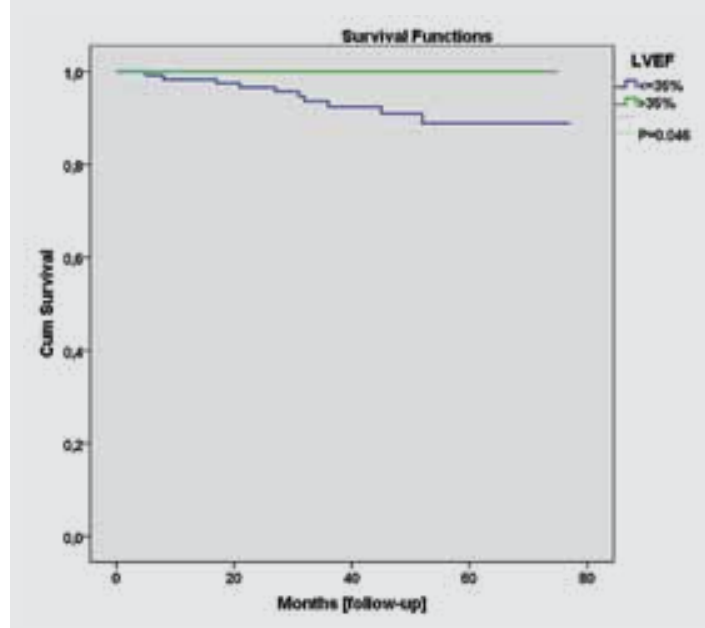

FIGURE 1. Survival curves according to left ventricular ejection fraction (LVEF).

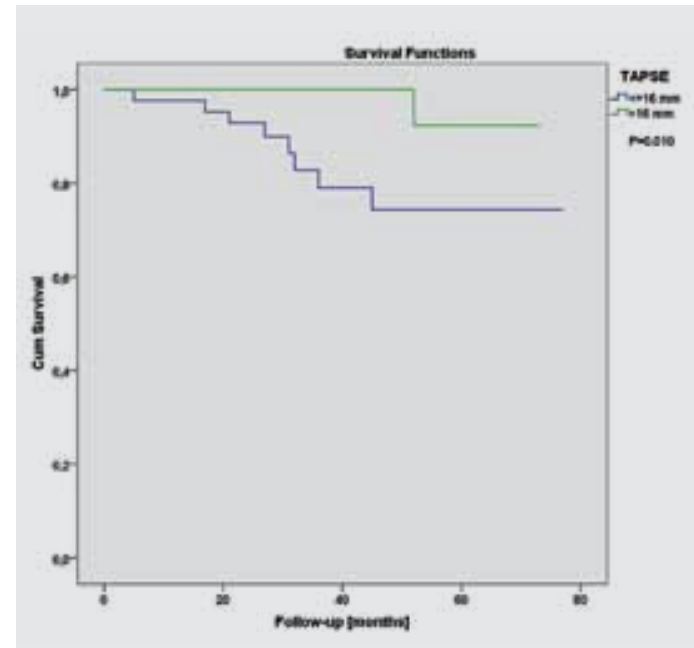

FIGURE 3. Survival curves according to tricuspid annular plane systolic excursion (TAPSE).

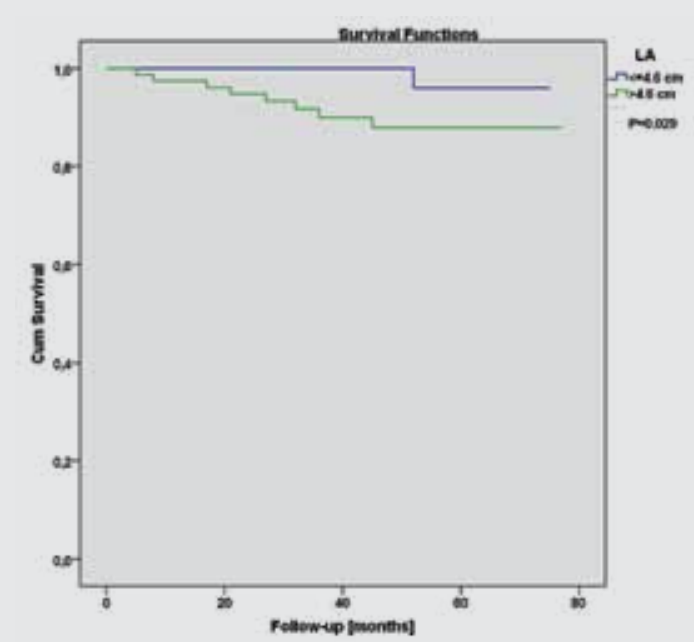

FIGURE 2. Survival curves according to left atrial diameter (LA).

Conclusion: Although sometimes considered obsolete in the modern era, "classical", easily obtainable echocardiographic parameters of cardiac structure and function are still reliable predictors of patient mortality in chronic HF. As expected, enlarged LA and LV, as well as reduced systolic function of both ventricles were all associated with adverse outcome.

\section{LITERATURE IIIIIIIIIIIIIIIIIIIIIIIIIIIIIIIIIIIIIIIIIIIIIIIIIIIIIIIIIIIIIIIIIIIIIIIIIIIIIIIIIIIIIIIIIIIIIIIIIIIIII}

1. Kirkpatrick JN, Vannan MA, Narula J, Lang RM. Echocardiography in heart failure: applications, utility, and new horizons. J Am Coll Cardiol. 2007 Jul 31;50(5):381-96. https://doi.org/10.1016/j.jacc.2007.03.048 